\title{
Quantitative investigation of the affinity of human respiratory syncytial virus phosphoprotein C-terminus binding to nucleocapsid protein
}

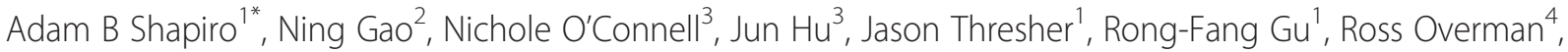 \\ Ian M Hardern ${ }^{4}$ and Graham $G$ Sproat ${ }^{4}$
}

\begin{abstract}
Background: There are no approved small molecule drug therapies for human respiratory syncytial virus (hRSV), a cause of morbidity and mortality in at-risk newborns, the immunocompromised, and the elderly. We have investigated as a potential novel hRSV drug target the protein-protein interaction between the C-terminus of the viral phosphoprotein (P) and the viral nucleocapsid protein $(\mathrm{N})$, components of the ribonucleoprotein complex that contains, replicates, and transcribes the viral RNA genome. Earlier work by others established that the $9 \mathrm{C}$-terminal residues of $\mathrm{P}$ are necessary and sufficient for binding to $\mathrm{N}$.
\end{abstract}

Methods: We used a fluorescence anisotropy assay, surface plasmon resonance and 2-D NMR to quantify the affinities of peptides based on the C terminus of P for RNA-free, monomeric N-terminal-truncated N(13-391). We calculated the contributions to the free energies of binding of $P$ to N(13-391) attributable to the C-terminal 11 residues, phosphorylation of the C-terminal 2 serine residues, the C-terminal Asp-Phe, and the phenyl ring of the C-terminal Phe.

Results: Binding studies confirmed the crucial role of the phosphorylated C-terminal peptide D(pS)DNDL(pS)LEDF for binding of $\mathrm{P}$ to RNA-free, monomeric N(13-391), contributing over $90 \%$ of the binding free energy at low ionic strength. The phenyl ring of the C-terminal Phe residue contributed an estimated $-2.7 \mathrm{kcal} / \mathrm{mole}$ of the free energy of binding, the C-terminal Asp-Phe residues contributed $-3.8 \mathrm{kcal} / \mathrm{mole}$, the sequence DSDNDLSLE contributed $-3.1 \mathrm{kcal} / \mathrm{mole}$, and phosphorylation of the $2 \mathrm{Ser}$ residues contributed $-1.8 \mathrm{kcal} / \mathrm{mole}$. Due to the high negative charge of the C-terminal peptide, the affinity of the P C-terminus for N(13-391) decreased as the ionic strength increased.

Conclusions: The results support the idea that the interaction of the C-terminal residues of $\mathrm{P}$ with $\mathrm{N}$ constitutes a protein-protein interaction hotspot that may be a suitable target for small-molecule drugs that inhibit viral genome replication and transcription.

Keywords: Respiratory syncytial virus, Nucleocapsid, Phosphoprotein, Phosphorylation, Protein-protein interaction, Fluorescence anisotropy, Surface plasmon resonance, Nuclear magnetic resonance spectroscopy

\footnotetext{
* Correspondence: adam.shapiro@astrazeneca.com

'Biology Department, Infection Innovative Medicines Unit, AstraZeneca R\&D Boston, Waltham, MA, USA

Full list of author information is available at the end of the article
} 


\section{Background}

Human respiratory syncytial virus (hRSV) is a nonsegmented negative sense RNA virus in the order Mononegavirales, the family Paramyxoviridae and the genus Pneumovirus, and is the cause of severe respiratory tract infections among newborns, immunocompromised people, and the elderly [1]. Current treatments are limited to antibody prophylaxis with palivizumab for high-risk newborns, general antiviral therapy with ribavirin, and supportive care. Efforts to develop anti-RSV vaccines and new drugs to prevent and treat the disease have so far been unsuccessful [2-4].

The genome of hRSV codes for 11 proteins. Four of these, the polymerase $(\mathrm{L})$, nucleocapsid protein $(\mathrm{N})$, phosphoprotein $(\mathrm{P})$ and transcription anti-termination factor (M2-1), along with the RNA genome, make up the ribonucleoprotein (RNP) complex responsible for transcription and replication of the RNA. Several types of low molecular weight compounds have been identified that appear to target the RNP. Mutations conferring resistance to the inhibitory effect of YM-53404 and related compounds on viral replication were found in the polymerase $\mathrm{L}[5,6]$. Mutations conferring resistance to RSV604 are found in the nucleocapsid N protein [7]. Liuzzi et al. [8] identified inhibitors of the mRNA capping function of the $\mathrm{L}$ protein, resistance mutations to which are found in the $\mathrm{L}$ protein. Thus the RNP is a viable target for compounds that inhibit RSV replication.

Several protein-protein interactions are involved in assembly of RNP. The $\mathrm{N}$ protein forms helical oligomers around which the RNA is wrapped $[9,10]$. P protein oligomerizes [11,12] and interacts with $\mathrm{N}$ [12-15], M2-1[16-20], and L [21-23]. M2-1 is a tetramer [19,24] and interacts with $\mathrm{N}$ [25-27] as well as P. These protein-protein interactions may offer suitable targets for antiviral drug discovery.

Protein-protein interactions can be difficult to disrupt with low molecular weight drugs if the interactions occur over a large, flat surface. Protein-protein interaction hotspots, confined areas with deep topological features, however, offer greater potential for drug discovery [28]. The information available concerning the interaction of the Cterminus of the RSV P protein with the $\mathrm{N}$ protein suggests that this interaction may occur at such a hotspot. A putative $\mathrm{P}$ binding region on the $\mathrm{N}$-terminal core domain of $\mathrm{N}$ was identified by Galloux et al. [13], including Lys 46, Met 50, Ile 53, Ser 131, Arg 132, Tyr 135, Arg 150, and His 151. Mutations of several residues in this domain to alanine reduced both viral RNA synthesis and the N-P interaction in vivo and in vitro. On the crystal structure of $\mathrm{N}$, these residues are clustered together, forming a potential $\mathrm{P}$ binding site with a hydrophobic cavity surrounded by several basic side chains. Remarkably, only the C-terminal 9 residues of P (Asp 233 to Phe 241) are necessary for binding to $\mathrm{N}$ in pull-down assays $[13,15]$. Moreover, changing just the $\mathrm{C}$-terminal phenylalanine residue of $\mathrm{P}$ to alanine abrogates both $\mathrm{N}$ binding and viral RNA synthesis [13]. These observations strongly support the existence of a P-N binding hotspot involving the Cterminus of $\mathrm{P}$ and the aforementioned $\mathrm{N}$-terminal core domain of $\mathrm{N}$.

The C-terminal 11 residues of P (Asp-Ser-Asp-AsnAsp-Leu-Ser-Leu-Glu-Asp-Phe) include 2 serine residues, Ser 232 and Ser 237, both of which have been observed to be phosphorylated, although the importance of their phosphorylation is unclear. Mazumder et al. [29] showed that purified recombinant $\mathrm{P}$ was selectively phosphorylated on Ser 237 by casein kinase II. Mazumder and Barik [30] found that mutation of Ser 237 to Ala abrogated RNA transcription by reconstituted RNP in vitro, whereas mutation of Ser 232 to Ala had no effect. In contrast, Barik et al. [31] found that Ser 232 was the major site of P phosphorylation when it was expressed in human cells or when unphosphorylated recombinant $\mathrm{P}$ was treated with a crude human cell extract. Sánchez-Seco et al. [32] found that Ser 232, not Ser 237, was the main site of phosphorylation of recombinant $\mathrm{P}$ in vitro by casein kinase II. Villanueva et al. [33] found that phosphorylation of $\mathrm{P}$ expressed in human cells was mainly on Ser 232 and to a lesser extent on Ser 237, based on the decreased level of phosphorylation when either residue was changed to Ala, but that mutation of either of these residues had little effect on viral transcription or replication. Only mutation of both residues combined with mutation of other probable sites of serine phosphorylation elsewhere in the protein substantially reduced, but did not completely eliminate, transcription and replication. Finally, Lu et al. [34] found that eliminating phosphorylation of Ser 232 and Ser 237 by mutation reduced $\mathrm{P}$ phosphorylation by $80 \%$ in infected cells, but had only modest effects on reporter gene expression and the N-P interaction. The mutant virus showed impaired replication in rodents compared with the wildtype virus, however. The inconsistencies in the results reported in the literature on this topic do not allow us to draw definitive conclusions regarding either the extent of phosphorylation of Ser 232 and Ser 237 or the roles of these residues in the functions of $\mathrm{P}$, including its interaction with $\mathrm{N}$.

We have taken a quantitative biophysical approach to investigate the $\mathrm{P}-\mathrm{N}$ protein-protein interaction with regard to the effect of phosphorylation of the C-terminal $\mathrm{N}$-binding peptide of $\mathrm{P}$ on residues 232 and 237 and the importance of the C-terminal Phe residue. In the process, we demonstrate 3 practical measurement systems fluorescence anisotropy, surface plasmon resonance, and 2-D NMR - that can be used as the first steps in drug discovery programs to identify inhibitors of the interaction. 


\section{Results}

Fluorescence anisotropy measurements of P C-terminal peptide binding to $\mathrm{N}(13-391)$

Peptides having the sequence of the $\mathrm{C}$-terminal 11 residues of RSV P protein (DSDNDLSLEDF) were labeled on the $\mathrm{N}$-terminus with the fluorophore BODIPY FL for fluorescence anisotropy-based measurements of binding to N(13391), an N-terminally truncated construct of RSV N protein that does not oligomerize [35]. The truncation makes the protein easier to overexpress in soluble form in bacteria than full-length $\mathrm{N}$. When purified from bacteria, the truncated $\mathrm{N}$ proteins used in this study had no detectable RNA associated with them. One peptide was unphosphorylated (BP1). The other was phosphorylated on both serine residues (BP5), corresponding to Ser 232 and Ser 237 of the $\mathrm{P}$ protein. Both peptides bound to the N(13-391) construct (Figure 1A). The affinity of the doubly phosphorylated peptide BP5 $\left(\mathrm{K}_{\mathrm{d}}=78 \pm 5\right.$ $\mathrm{nM}$ ) was about 10 times that of the unphosphorylated peptide $\mathrm{BP} 1\left(\mathrm{~K}_{\mathrm{d}}=760 \pm 20 \mathrm{nM}\right)$. This result indicates that phosphorylation of the serine residues in the C-terminus of $\mathrm{P}$ is likely to affect the affinity of the $\mathrm{N}-\mathrm{P}$ binding interaction. The anisotropy change was also larger for BP5 than BP1. Subsequent experiments were performed with BP5 because of the lower $\mathrm{N}(13-391)$ concentration required to perform competition experiments and larger signal compared with BP1.

Considering the highly negative charge of the doubly phosphorylated P C-terminal peptide due to the presence of 2 phosphate groups and 5 acidic side chains within the 11 residue peptide, we reasoned that electrostatic interactions with $\mathrm{N}$ would likely play a significant role in the interaction between them. Moreover, the putative P binding site on $\mathrm{N}$ contains several basic amino acid side chains [13]. In support of this hypothesis, we found that the affinity of BP5 for $\mathrm{N}(13-391)$ diminished as the ionic strength increased (Figure 1B). Subsequent experiments were performed in a low-ionic strength buffer in order to maximize the affinity of BP5 for N(13-391), thereby minimizing the amount of protein required.
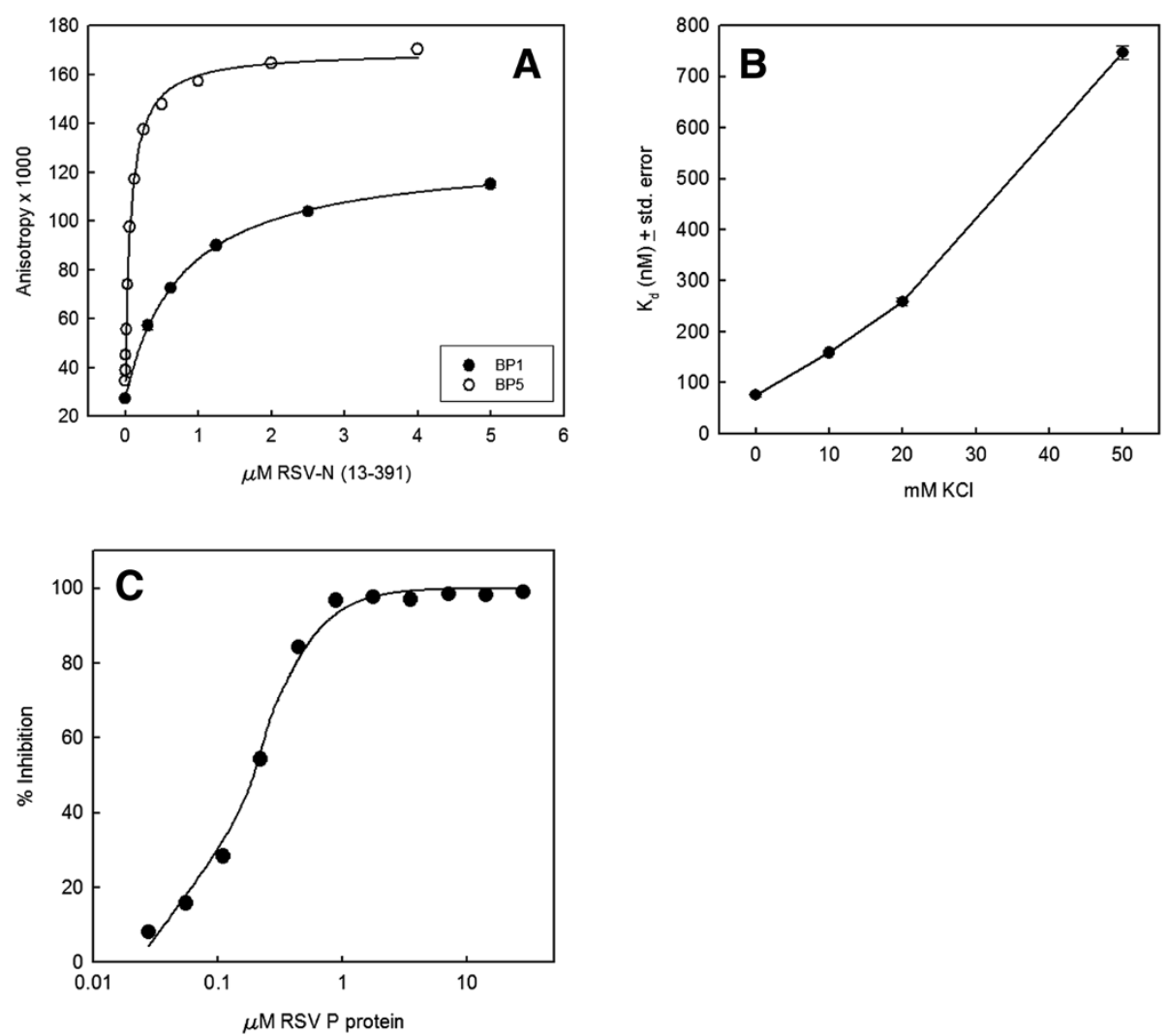

Figure 1 Fluorescence anisotropy measurements of $\mathrm{P}$ C-terminal peptide binding to $\mathrm{N}(13-391)$, effect of $\mathrm{KCl}$, and competition by full-length P. (A) Affinity of unphosphorylated and doubly phosphorylated P-derived C-terminal peptides BP1 and BP5, respectively, for N(13-391). Data points and error bars represent the means and standard deviations, respectively, of 3 replicates. The error bars are mostly hidden by the data points. The $\mathrm{K}_{\mathrm{d}} \mathrm{s}$ for BP1 and BP5 were $760 \pm 20 \mathrm{nM}$ and $78 \pm 5 \mathrm{nM}$, respectively (best-fit value \pm standard error of fit). (B) Effect of $\mathrm{KCl}$ concentration on affinity of BP5 for N(13-391). $K_{d} s$ were measured with N(13-391) concentrations ranging from 1.95 to $2000 \mathrm{nM}$ in triplicate. The data were fit as above. Data points and error bars represent the best-fit $K_{d} s$ and the standard errors of the fits, respectively. (C) Inhibition of BP5 binding to N(13-391) by full-length $\mathrm{P}$ protein. The $\mathrm{IC}_{50}$ was $180 \pm 10 \mathrm{nM}$ (best-fit value \pm standard error of fit). 


\section{Effect of P C-terminal peptide phosphorylation on binding to N(13-391) measured by fluorescence anisotropy}

The effect of phosphorylation of each of the two serine residues in the $\mathrm{C}$-terminal peptide on its affinity for $\mathrm{N}$ (13-391) was investigated by competition with BP5 binding (Table 1). Phosphorylation of either serine residue substantially increased the affinity of the peptide compared with the unphosphorylated peptide, 7-fold for the $\mathrm{N}$-terminal serine and 10 -fold for the $\mathrm{C}$-terminal serine. Phosphorylation of both serine residues resulted in an additional affinity enhancement of approximately 3 -fold greater than observed for phosphorylation of one residue. As a result, the affinity of the doubly phosphorylated peptide was 20-25-fold higher than the affinity of the unphosphorylated peptide. This is consistent with the above observation that the affinity of doubly phosphorylated BP5 is 10-fold higher than the affinity of unphosphorylated BP1.

The $K_{d} s$ of the peptides in the fluorescence anisotropy experiments are approximately $1 / 2$ the $\mathrm{IC}_{50} \mathrm{~s}$ because the $\mathrm{N}(13-391)$ concentration used was equal to its $\mathrm{K}_{\mathrm{d}}$ with BP5. Therefore, the $\mathrm{K}_{\mathrm{d}} \mathrm{s}$ of DSDNDLSLEDF and $\mathrm{D}(\mathrm{pS}) \mathrm{DNDL}$ $(\mathrm{pS}) \mathrm{LEDF}$ were about 7.6 and $0.34 \mu \mathrm{M}$, respectively. These $\mathrm{K}_{\mathrm{d}} \mathrm{s}$ are considerably higher than the $\mathrm{K}_{\mathrm{d}} \mathrm{s}$ of the same peptides bearing an N-terminal BODIPY FL fluorophore, BP1 $(0.76 \mu \mathrm{M})$ and BP5 $(0.078 \mu \mathrm{M})$, respectively. This is most likely due to the hydrophobic character of the fluorophore, which tends to enhance the affinity of a ligand as long as the fluorophore does not cause a steric clash.

\section{Effect of changing the P C-terminal peptide's C-terminal} residue on binding to $\mathrm{N}(13-391)$ measured by fluorescence anisotropy

The C-terminal phenylalanine residue of $\mathrm{P}$ is crucial for binding of $\mathrm{P}$ to $\mathrm{N}$, and mutation to alanine abrogates

Table 1 Competition by RSV-P C-terminal-derived peptides with BP5 binding to RSV-N(13-391)

\begin{tabular}{lll}
\hline & \multicolumn{1}{l}{$\mathbf{I}_{\mathbf{5 0}}(\boldsymbol{\mu} \mathbf{M}) \pm$ standard error } & \\
\cline { 2 - 3 } Peptide sequence & Fluorescence anisotropy & SPR \\
\hline DSDNDLSLEDF & $15.3 \pm 0.4$ & $230 \pm 30$ \\
DSDNDLSLEDA & $>200$ & $\mathrm{ND}$ \\
D(pS)DNDLSLEDF & $2.17 \pm 0.04$ & $44 \pm 3$ \\
DSDNDL(pS)LEDF & $1.51 \pm 0.03$ & $31 \pm 2$ \\
D(pS)DNDL(pS)LEDF & $0.61 \pm 0.01,0.74 \pm 0.02$ & $13.6 \pm 0.3$ \\
D(pS)DNDL(pS)LEDA & $69 \pm 2$ & $\mathrm{ND}$ \\
DF & $1450 \pm 50$ & $\mathrm{ND}$ \\
\hline Compen
\end{tabular}

Competition was measured by the fluorescence anisotropy assay and with $\mathrm{N}$ (13-391) binding to $\mathrm{P}$ by SPR. Competitor peptide concentrations ranged from 0.2 to $200 \mu \mathrm{M}$. The $\mathrm{IC}_{50}$ for $\mathrm{D}(\mathrm{pS}) \mathrm{DNDL}(\mathrm{pS}) \mathrm{LEDF}$ was measured twice using fluorescence anisotropy. $I_{50} \mathrm{~s}$ from the fluorescence anisotropy assay are approximately twice the $K_{d} s$ of the competitors because the $N(13-391)$ concentration was set at the $K_{d}$ for the interaction of $N(13-391)$ with BP5. ND, not done. binding and viral replication [13]. The effect of changing the C-terminal Phe residue to Ala on competition by the P C-terminal peptide with BP5 binding to N(13-391) was substantial (Table 1). For unphosphorylated peptides, the $\mathrm{IC}_{50}$ increased by more than 13 -fold when Phe was changed to Ala. The $\mathrm{IC}_{50}$ of the Ala-modified peptide exceeded the highest concentration tested $(200 \mu \mathrm{M})$. Inhibition by $200 \mu \mathrm{M}$ peptide was about $25 \%$, so the true $\mathrm{IC}_{50}$ can be estimated to have been approximately 600 $\mu \mathrm{M}$, assuming a Hill slope of 1 , which was typical for these measurements. Thus the $\mathrm{IC}_{50}$ shifted upward about 40fold when Phe was replaced with Ala in the unphosphorylated peptide. For the phosphorylated peptides, changing Phe to Ala resulted in an upward shift of the $\mathrm{IC}_{50}$ by approximately 100 -fold. These results are consistent with the literature showing that the $\mathrm{C}$-terminal $\mathrm{Phe}$ of $\mathrm{P}$ is a crucial binding determinant for its interaction with $\mathrm{N}$.

\section{Competition by full-length P protein with P C-terminal} peptide binding measured by fluorescence anisotropy Full-length $\mathrm{P}$ protein produced in insect cells was tested for its ability to compete with BP5 binding to N(13-391). As determined by mass spectrometry, the $\mathrm{P}$ protein consists of a mixture of unphosphorylated, singly and doubly phosphorylated species, with the singly phosphorylated species most abundant (data not shown). The locations of the phosphorylated residues are unknown and may differ between molecules. Figure $1 \mathrm{C}$ shows that this $\mathrm{P}$ protein competed with an $\mathrm{IC}_{50}$ of $180 \mathrm{nM}\left(\mathrm{K}_{\mathrm{d}} \sim 90 \mathrm{nM}\right)$. Interestingly, this is only about 4-fold greater affinity than was measured for the doubly phosphorylated C-terminal peptide $\mathrm{D}(\mathrm{pS}) \mathrm{DNDL}(\mathrm{pS}) \mathrm{LEDF}$. This observation is consistent with the hypothesis that the interaction of $\mathrm{P}$ with $\mathrm{N}$ is largely, if not entirely, determined by the last several residues at the $\mathrm{C}$-terminus of $\mathrm{P}$.

\section{Surface plasmon resonance measurements}

The P C-terminus-derived peptides were tested for their ability to compete with soluble $\mathrm{N}(13-391)$ binding to immobilized P using SPR. The SPR results are consistent, in terms of rank order of potencies, with the results from the fluorescence anisotropy measurements, although the $\mathrm{IC}_{50} \mathrm{~S}$ are higher for the SPR measurements (Figure 2 and Table 1). This is likely due to the higher ionic strength used in the SPR experiments (see Figure 1B). The SPR results demonstrate that the fluorescence anisotropy assay of the inhibition by peptides of BP5 binding to N(13-391) is a reliable surrogate for the inhibition by peptides of $\mathrm{N}$ (13-391) binding to $\mathrm{P}$.

\section{2-D NMR measurements}

The importance of the C-terminal Phe residue for $\mathrm{N}$ binding was studied by measuring the ability of the Pderived C-terminal dipeptide Asp-Phe to compete with 


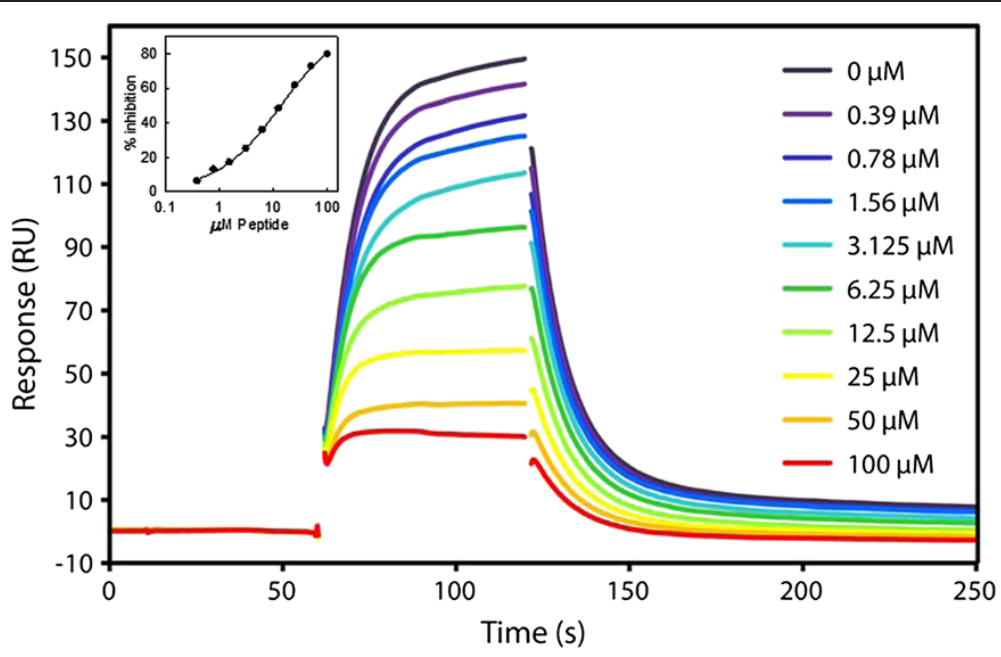

Figure 2 Inhibition of N(13-391) binding to immobilized P protein by $\mathrm{D}(\mathrm{pS}) \mathrm{DNDL}(\mathrm{pS})$ LEDF peptide measured by SPR. Concentrations of the peptide are indicated on the figure. The $I C_{50}$ (curve shown in inset) was $13.7 \pm 0.3 \mu \mathrm{M}$ (best-fit value \pm standard error of the best-fit value). The concentration of N(13-391) was $100 \mathrm{nM}$. Injection spikes have been deleted from the image for clarity.
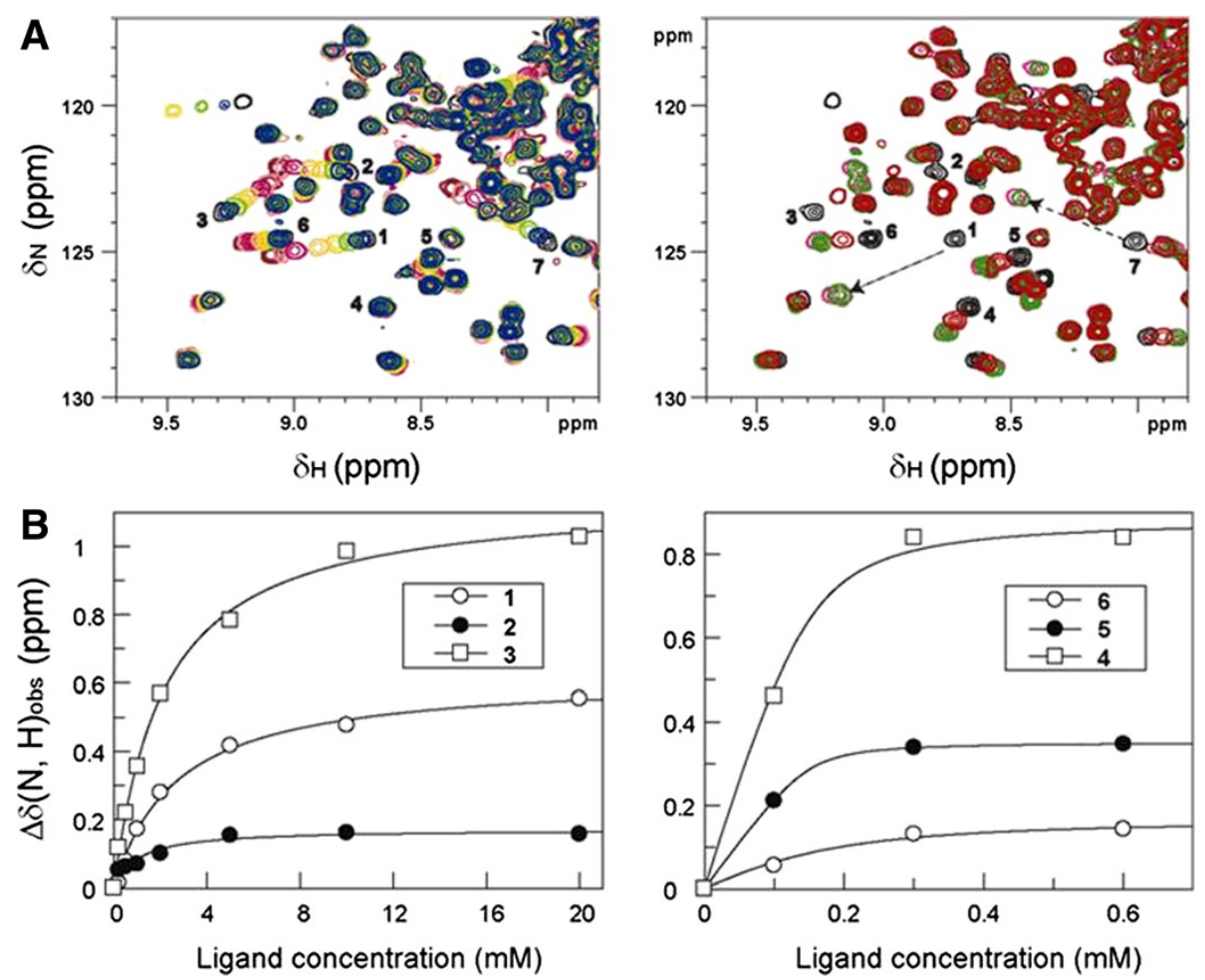

Figure 3 Binding of Asp-Phe (left) and D(pS)DNDL(pS)LEDF (right) to N(31-252). (A) Contour plots of backbone amide resonances of $0.15 \mathrm{mM}$ ${ }^{15} \mathrm{~N}$-labeled N(31-252) obtained from two-dimensional $\left[{ }^{15} \mathrm{~N},{ }^{1} \mathrm{H}\right]$ TROSY spectra recorded at a range of ligand concentrations. Numbered resonances correspond to the graphs in panel $\mathbf{B}$. Dotted arrows denote the putative directions of shift for resonances 1 and 7 . The missing resonances of 1 and 7 in the presence of $0.1 \mathrm{mM} \mathrm{D}(\mathrm{pS}) \mathrm{DNDL}(\mathrm{pS}) \mathrm{LEDF}$ indicate the binding interaction is in the intermediate exchange regime [36]. (B) Chemical shift perturbations $\Delta \delta(\mathrm{N}, \mathrm{H})_{\text {obs }}$ of selected amide resonances of ${ }^{15} \mathrm{~N}$-labeled N(31-252) as a function of ligand concentration. The symbols represent the experimental data and the lines are global best-fit theoretical curves for a simple binding isotherm. The best-fit values \pm standard error of the fit of $K_{d} s$ were $2.6 \pm 0.3 \mathrm{mM}$ for Asp-Phe (left) and $74 \pm 4 \mu \mathrm{M}$ for D(pS)DNDL(pS)LEDF (right). 
BP5 binding to $\mathrm{N}(13-391)$. The $\mathrm{IC}_{50}$ was $1.45 \mathrm{mM}$ (Table 1). Two-dimensional NMR experiments with ${ }^{15} \mathrm{~N}$-labeled $\mathrm{N}(31-252)$ confirmed that this dipeptide binds to $\mathrm{N}(31-252)$, as shown by the shift in position of several crosspeaks (Figure 3A). When the longer peptide $\mathrm{D}(\mathrm{pS}) \mathrm{DNDL}(\mathrm{pS}) \mathrm{LEDF}$ was used, additional crosspeaks shifted position (Figure 4). This result demonstrates that the longer peptide makes more contacts with the $\mathrm{P}$ binding site of $\mathrm{N}(31-252)$ than the dipeptide. The $\mathrm{K}_{\mathrm{d}} \mathrm{s}$ of Asp-Phe and $\mathrm{D}(\mathrm{pS}) \mathrm{DNDL}(\mathrm{pS}) \mathrm{LEDF}$ measured by NMR were 2.6 $\mathrm{mM}$ and $74 \mu \mathrm{M}$, respectively (Figure $3 \mathrm{~B}$ ). These $\mathrm{K}_{\mathrm{d}} \mathrm{s}$ were higher than those measured by the fluorescence anisotropy assay because of the higher ionic strength of the buffer in which the NMR experiments were performed. As expected, this ionic strength effect was greater for the more highly charged peptide $\mathrm{D}(\mathrm{pS}) \mathrm{DNDL}(\mathrm{pS}) \mathrm{LEDF}$ than for Asp-Phe.

\section{Discussion}

Using the relationships $\Delta \mathrm{G}=\mathrm{RT} \ln \mathrm{K}_{\mathrm{d}}$ and $\mathrm{IC}_{50}=2 \times \mathrm{K}_{\mathrm{d}}$, we can obtain approximate values for $\Delta G$ of binding for the components of the C-terminal peptide of $\mathrm{P}$ to RNAfree $\mathrm{N}(13-391)$ in $10 \mathrm{mM}$ Tris- $\mathrm{HCl}(\mathrm{pH} 7.5)$ at $21^{\circ} \mathrm{C}$. This calculation shows that Asp-Phe (DF) contributes -3.8 $\mathrm{kcal} / \mathrm{mole}$ out of $-8.7 \mathrm{kcal} / \mathrm{mole}$ for $\mathrm{D}(\mathrm{pS}) \mathrm{DNDL}(\mathrm{pS})$ LEDF. The contribution of the phenyl ring of the Phe residue can be estimated by comparing $\Delta \mathrm{G}$ of binding for $\mathrm{D}(\mathrm{pS}) \mathrm{DNDL}(\mathrm{pS}) \mathrm{LEDF}(-8.7 \mathrm{kcal} / \mathrm{mole})$ to that for D (pS)DNDL(pS)LEDA $(-6.0 \mathrm{kcal} / \mathrm{mole})$, hence $\Delta \Delta \mathrm{G}=-2.7$ $\mathrm{kcal} / \mathrm{mole}$, corresponding to a $\mathrm{K}_{\mathrm{d}}$ for the phenyl ring of 10 $\mathrm{mM}$. The $\Delta \mathrm{G}$ of binding attributable to DSDNDLSLE can be estimated by subtracting the $\Delta \mathrm{G}$ of binding of DF (-3.8 $\mathrm{kcal} / \mathrm{mole}$ ) from the $\Delta \mathrm{G}$ of binding of DSDNDLSLEDF $(-6.9 \mathrm{kcal} / \mathrm{mole})$ to obtain a value of $-3.1 \mathrm{kcal} / \mathrm{mole}$ for this part of the $\mathrm{C}$-terminal peptide, which contains 5 acidic side chains (not counting the $\mathrm{C}$-terminus) that could interact with basic residues in the $\mathrm{P}$ binding site of $\mathrm{N}(13-391)$. The $\Delta \mathrm{G}$ of binding contributed by phosphorylation of both
Ser residues can be estimated by comparing $\Delta \mathrm{G}$ of binding for DSDNDLSLEDF $(-6.9 \mathrm{kcal} /$ mole) to that for $\mathrm{D}(\mathrm{pS})$ DNDL(pS)LEDF $(-8.7 \mathrm{kcal} / \mathrm{mole})$, hence $\Delta \Delta \mathrm{G}=-1.8 \mathrm{kcal} /$ mole. Interestingly, these estimates indicate that the phenyl ring of the C-terminal Phe residue contributes more free energy of binding than both phosphate moieties, that over $40 \%$ of the free energy of binding of $\mathrm{D}(\mathrm{pS}) \mathrm{DNDL}(\mathrm{pS}) \mathrm{LEDF}$ comes from the DF dipeptide, and that over $90 \%$ of the free energy of binding of the full-length $\mathrm{P}$ used in this experiment can be attributed to the $\mathrm{D}(\mathrm{pS}) \mathrm{DNDL}(\mathrm{pS}) \mathrm{LEDF}$ peptide. These calculations are oversimplified by not taking all factors into account, such as the fact that DF and $\mathrm{D}(\mathrm{pS})$ DNDL(pS)LEDF have free $\mathrm{N}$-termini that are parts of amide bonds in the longer peptides and the full-length protein, respectively, and the unknown phosphorylation status of the C-terminal serine residues of the full-length P. Nevertheless, the calculations are helpful in demonstrating that most of the affinity of $\mathrm{P}$ for $\mathrm{N}(13-391)$ is due to the last several residues at the $\mathrm{C}$-terminus of $\mathrm{P}$, and that much of the affinity of these $\mathrm{C}$-terminal residues is due to the binding of the last 2 residues. This observation is consistent with the idea that the N-P interaction can be considered to be a protein-protein interaction hotspot.

The relatively small energetic contribution of Ser 232 and Ser 237 phosphorylation to the affinity of $\mathrm{D}(\mathrm{pS})$ DNDL(pS)LEDF for binding to N(13-391) (-1.8 kcal/mole), combined with the observation that phosphorylation of either of the serine residues has nearly as much effect on the affinity as phosphorylation of both, suggests a possible explanation for the inconsistent results reported in the literature on the importance of Ser 232 and Ser 237 for RSV transcription and replication (see Introduction). The extent to which P C-terminal phosphorylation affects RNP assembly will depend on the local concentrations of the $\mathrm{P}$ and/or $\mathrm{N}$ proteins. If at least one of these concentrations is well in excess of the N-P binding $K_{d}$ when $P$ is unphosphorylated, then the interaction will not be significantly affected by phosphorylation. In contrast, if the concentrations of both
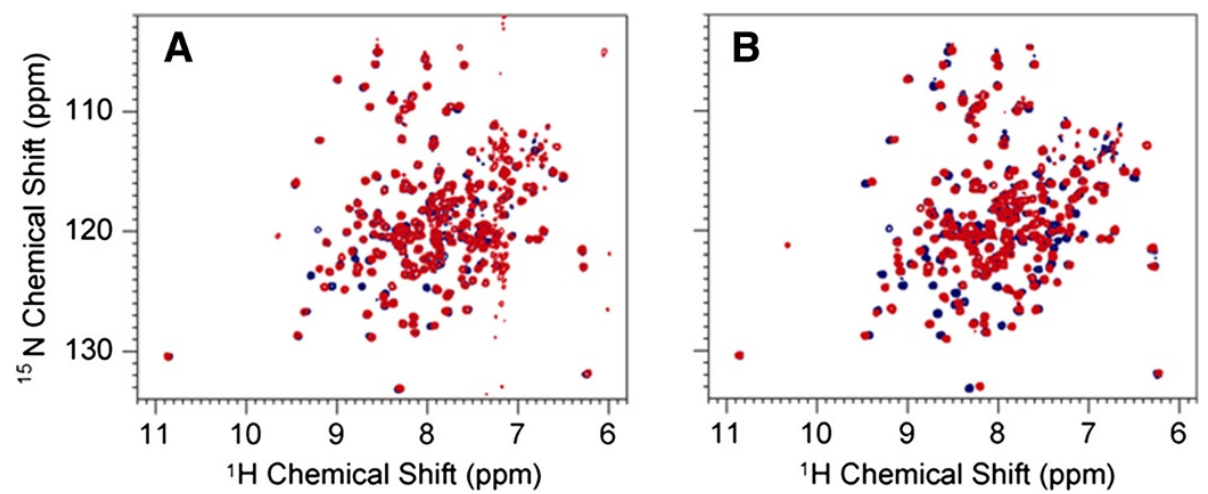

Figure 4 Backbone amide resonances of ${ }^{15} \mathrm{~N}$-labeled N(31-252) from two-dimensional $\left[{ }^{15} \mathrm{~N},{ }^{1} \mathrm{H}\right]$ TROSY spectra. Blue, no ligand. Red, peptide ligand. The concentration of N(31-252) was $0.15 \mathrm{mM}$. (A) $2 \mathrm{mM}$ Asp-Phe. (B) $0.3 \mathrm{mM} \mathrm{D(pS)DNDL(pS)LEDF.}$ 
of the proteins are lower than the $K_{d}$, then phosphorylation, by lowering the $\mathrm{K}_{\mathrm{d}}$, will drive the binding interaction. It may be that the $\mathrm{N}$ and $\mathrm{P}$ concentrations present in the various reported experiments differed sufficiently for the extent of $\mathrm{P}$ C-terminal phosphorylation to affect the efficiency of RNP assembly differently between them. For example, Mazumder and Barik [30] used in vitro reconstituted RNP, whereas Lu et al. [34] used infected cells.

In a comparison of the sequences of residues 231-241 in 163 publicly available sequences of RSV P protein in PubMed, the 3rd-to-last residue, Glu 239, is frequently conservatively replaced by Asp, and there is one instance each of Asn 234 being replaced by Asp and Ser 237 being replaced by Leu. The other residues are invariant. Similarly, the residues of $\mathrm{N}$ protein identified by Galloux et al. [13] as being involved in binding to P - Lys 46, Met 50, Ile 53, Ser 131, Arg 132, Tyr 135, Arg 150, and His 151 - are completely conserved among 126 published full-length $\mathrm{N}$ sequences in PubMed. This high degree of sequence conservation is consistent with the importance of $\mathrm{P}$ residues 231-241 and the aforementioned $\mathrm{N}$ residues for binding of $\mathrm{P}$ and $\mathrm{N}$.

\section{Conclusion}

Three biophysical methods were used in this research: (1) a fluorescence anisotropy-based binding assay to measure competition by P-derived peptides and full-length $\mathrm{P}$ with binding of BP5 (D(pS)DNDL(pS)LEDF labeled on the $\mathrm{N}$-terminus with BODIPY FL) to N(13-391), (2) surface plasmon resonance (SPR) to measure the competition by P-derived peptides with binding of $\mathrm{N}(13-391)$ to $\mathrm{P}$, and (3) 2-D NMR to measure direct binding of Asp-Phe $\mathrm{D}(\mathrm{pS})$ DNDL(pS)LEDF to N(31-252). Each of these methods is suitable for screening compounds for binding to the N-P protein-protein interaction hotspot. Because of their relatively low throughput, SPR and NMR are most useful for screening small libraries of hundreds of very low molecular weight $(<300 \mathrm{Da})$ fragments. The fluorescence anisotropy assay can be used to screen much larger libraries consisting of hundreds of thousands of compounds because it is a high-throughput assay. The active samples from such a screen could then be counterscreened to remove false positives due to detection artifacts using SPR and/or NMR. Thus the methods used here could be used to begin a drug discovery program aimed at identifying competitive inhibitors of the binding of RSV P protein to $\mathrm{N}$ that work by occupying the $\mathrm{P}$ binding site of $\mathrm{N}$.

\section{Methods \\ Peptides}

Oligopeptides corresponding to residues 231-241 of RSV $\mathrm{P}$ protein, including phosphorylation, were synthesized and purified by Biopeptide Co. Inc. (San Diego, CA). Purities of peptides were at least $95 \% . \mathrm{N}$ - and C-termini were uncapped. Asp-Phe was from Sigma.

\section{Preparation of BODIPY-FL-labeled peptides 1 and 5 (BP1 and BP5)}

One $\mu$ mole $(1.3 \mathrm{mg}$ ) of peptide 1 (DSDNDLSLEDF) and $10 \mu$ moles $(5 \mathrm{mg}$ ) of BODIPY FL sulfosuccinimidyl ester (SSE) (Life Technologies) were dissolved in $100 \mu \mathrm{l}$ of fresh $0.1 \mathrm{M} \mathrm{NaHCO}_{3}$ and reacted for 1 hour in darkness at room temperature. Peptide $5(\mathrm{D}(\mathrm{pS}) \mathrm{DNDL}(\mathrm{pS}) \mathrm{LEDF})$, where $(\mathrm{pS})$ is phosphoserine, $(1.2 \mathrm{mg}, 0.84 \mu \mathrm{mole})$ and $10 \mu$ moles of BODIPY FL SSE were dissolved in $400 \mu \mathrm{l}$ of fresh $0.2 \mathrm{M}$ $\mathrm{NaHCO}_{3}+50 \mu \mathrm{l}$ of dimethyl sulfoxide and reacted for 2.75 hours at room temperature. In each case, the solution was applied to a $1 \times 18$-cm column of Sephadex LH-20 (Sigma) equilibrated with water. The column was eluted with water and fractions were collected. Liquid chromatography-mass spectrometry (LC-MS) was used to select fractions having the expected mass for the labeled peptide (1543 Da for BP1, $1701 \mathrm{Da}$ for BP5) and little or no unlabeled peptide. For BP5, LC-MS also showed evidence of a $1682 \mathrm{Da}$ species, suggesting loss of a fluorine atom, probably during the analysis. The concentration of the peptides was determined by the BODIPY FL absorbance at $504 \mathrm{~nm}$ using an extinction coefficient in water of $91,000 \mathrm{M}^{-1} \mathrm{~cm}^{-1}$.

\section{Mass spectrometry of peptides}

The LC-MS analysis was performed on a Triple TOF $5600+$ (AB Sciex, Redwood City, CA) equipped with a DuoSpray Ion Source and a Shimadzu LC 20-AD HPLC system (Shimadzu Scientific Instruments, Marlborough, MA). Separation was achieved on a 2.1 x $30 \mathrm{~mm}$ XBridge C18 column (Waters, Milford, MA) with a gradient of acetonitrile $(5-90 \%)$ in $0.1 \%$ formic acid for $3 \mathrm{~min}$ following 1 $\mathrm{min}$ at $5 \%$ acetonitrile at a flow rate of $0.4 \mathrm{ml} / \mathrm{min}$ and column temperature of $30^{\circ} \mathrm{C}$. LC-MS data was acquired in the TOF MS mode for $\mathrm{m} / \mathrm{z}$ + from 100 to 2000. Nebulizer gas (GS1), heater gas (GS2), and curtain gas were set at 60,70 , and $30 \mathrm{psi}$, respectively. The source temperature was $600^{\circ} \mathrm{C}$. Ion spray voltage was $5500 \mathrm{~V}$. Declustering voltage was $100 \mathrm{~V}$.

\section{Fluorescence anisotropy assays}

Samples of $10 \mu \mathrm{l}$ containing peptides and proteins as indicated were prepared in buffer composed of $10 \mathrm{mM}$ Tris- $\mathrm{HCl}(\mathrm{pH} 7.5)+0.01 \%$ Brij-35 detergent (Pierce SurfactAmps-35, Thermo Fisher Scientific, Rockford, IL) in lowvolume 384-well black polystyrene assay plates (Thermo Fisher Scientific, Hudson, NH). After a 5 minute incubation, fluorescence anisotropy was measured with a Pherastar plate reader (BMG Labtech, Cary, NC) equipped with a filter module having a $485 \mathrm{~nm}$ excitation filter and $520 \mathrm{~nm}$ emission filters with polarizers. The focal height was $10.8 \mathrm{~mm}$. Each measurement used 50 flashes. The 
parallel and perpendicular detector gains were set to 392 and 366 in order to produce an anisotropy of about 0.03 in the absence of binding.

For measurements of fluorescent peptide $\mathrm{K}_{\mathrm{d}} \mathrm{s}$ with RSV$\mathrm{N}(13-391), \mathrm{BP} 1$ and BP5 concentrations were $100 \mathrm{nM}$ and $25 \mathrm{nM}$, respectively. The averages of triplicate fluorescence anisotropy measurements made at each RSV-N(13-391) concentration were fit to the equation

$$
\mathbf{y}=\mathbf{y}_{o}+\mathbf{a}[\mathbf{N}] /\left(\mathbf{K}_{\mathbf{d}}+[\mathbf{N}]\right)
$$

where $\mathbf{y}$ is the anisotropy, $\mathbf{y}_{\mathbf{o}}$ is the anisotropy of peptide alone, [N] is the RSV-N(13-391) concentration, and $\mathbf{y}_{\mathbf{o}}+$ $\mathbf{a}$ is the anisotropy of fully bound peptide. The $\mathrm{K}_{\mathrm{d}} \mathrm{s}$ were not corrected for $18 \%$ and $14 \%$ decreases in the fluorescence intensities of BP1 and BP5, respectively, upon binding.

For $\mathrm{IC}_{50}$ measurements by competitors, the $\mathrm{BP} 5$ and RSV-N(13-391) concentrations were 25 and $75 \mathrm{nM}$, respectively. The averages of triplicate anisotropy measurements made at each competitor concentration were used to calculate \% inhibition using the equation

$$
\% \text { inhibition }=100\left[1-\left(r-r_{\min }\right) /\left(r_{\max }-r_{\min }\right)\right]
$$

where $\mathbf{r}$ is the anisotropy at the competitor concentration, $\mathbf{r}_{\min }$ is the anisotropy with no RSV-N(13-391), and $\mathbf{r}_{\max }$ is the anisotropy with no competititor. The \% inhibition values were used to determine the $\mathrm{IC}_{50}$ by nonlinear regression using the equation

$$
\% \text { inhibition }=100[\mathrm{C}]^{\mathrm{b}} /\left(\mathrm{IC}_{50}+[\mathrm{C}]^{\mathrm{b}}\right)
$$

where $[\mathbf{C}]$ is the competitor concentration and $\mathbf{b}$ is the Hill slope.

All fluorescence anisotropy measurements were performed at ambient temperature, approximately $21^{\circ} \mathrm{C}$.

\section{Surface plasmon resonance (SPR)}

SPR experiments were performed on a Biacore T200 using Series S NTA sensor chips (GE Healthcare). His $10^{-}$ RSV P protein was immobilized on the surface using the nickel-capture amine-couple approach. The immobilization buffer consisted of $10 \mathrm{mM}$ HEPES-NaOH ( $\mathrm{pH}$ 7.5), 150 $\mathrm{mM} \mathrm{NaCl}, 0.1 \mathrm{mM}$ EDTA, $1 \mathrm{mM}$ tris(2-carboxyethyl) phosphine hydrochloride (TCEP) and $0.005 \%(\mathrm{v} / \mathrm{v})$ Tween20. The surface was activated for His-tag capture by injecting $500 \mu \mathrm{M} \mathrm{NiSO}{ }_{4}$ for $60 \mathrm{~s}$ at a flow rate of $30 \mu \mathrm{l} / \mathrm{min}$. Subsequent activation for amine coupling was achieved by injecting a mixture of $200 \mathrm{mM}$ 1-ethyl-3-[3-dimethylaminopropyl]carbodiimide and $50 \mathrm{mM} N$-hydroxysuccinimide (NHS) for $7 \mathrm{~min}$ at flow rate $10 \mu \mathrm{l} / \mathrm{min}$. His ${ }_{10}-\mathrm{P}$ protein was diluted in immobilization buffer to a final concentration of $6 \mu \mathrm{M}$. The protein was immobilized to $\sim 6000$ resonance units $(\mathrm{RU})$ by applying short $(1-4 \mu \mathrm{l})$ pulses of protein at $5 \mu \mathrm{l} / \mathrm{min}$ until the desired immobilization level was achieved. Residual NHS was blocked by a $7 \mathrm{~min}$ injection of $0.1 \mathrm{M}$ Tris- $\mathrm{HCl}(\mathrm{pH} 8.0)$ at $10 \mu \mathrm{l} / \mathrm{min}$. Finally, the nickel was stripped from the surface using a $60 \mathrm{~s}$ injection of $350 \mathrm{mM}$ EDTA at a flow rate of $30 \mu \mathrm{l} / \mathrm{min}$.

Inhibition assays were carried out in $20 \mathrm{mM}$ HEPES$\mathrm{NaOH}$ (pH 7.5), $100 \mathrm{mM} \mathrm{NaCl}, 1$ mM EDTA, 1 mM TCEP, $0.005 \%(\mathrm{v} / \mathrm{v})$ Tween 20 and 1\% (v/v) DMSO at a constant concentration of $100 \mathrm{nM}$ RSV N(13-391). Peptides were mixed with $\mathrm{N}(13-391)$ in a 9-point concentration series of 2 -fold dilutions from a top concentration of $100 \mu \mathrm{M}$. Three blanks were included for determining the maximum binding response. Samples were allowed to come to equilibrium for $30 \mathrm{~min}$ before injection at $40 \mu \mathrm{l} / \mathrm{min}$ for $60 \mathrm{~s}$ followed by a $180 \mathrm{~s}$ dissociation period. To monitor surface integrity, positive and negative controls consisting of $100 \mathrm{nM}$ RSV $\mathrm{N}(31-252)$ and assay buffer, respectively, were run every 12 cycles. To correct for DMSO mismatches, three cycles of 8 solvent correction samples in the range $0-2 \%$ (v/v) DMSO were run at the beginning, middle and end of the experiment.

Data were analyzed using the Biacore T200 Evaluation Software V 2.0. Sensorgram data was reference-subtracted and solvent-corrected before the binding report point was extracted for each concentration at a time $4 \mathrm{~s}$ before the end of the injection. These data were used to calculate the percent inhibition according to the following equation: \% Inhibition $=100 *(1-$ Response(conc) $/$ Response_max), where Response_max is the average report point extracted from the 3 blank runs. Percent inhibition was plotted versus concentration and fit to a 4-parameter logistic Hill Equation (see above) for determining the peptide $\mathrm{IC}_{50}$.

\section{2-D NMR}

NMR spectra were acquired at $298 \mathrm{~K}$ with a $600 \mathrm{MHz}$ NMR instrument (Bruker, Billerica MA) equipped with an AVANCE III console and a triple-resonance cryogenic probe. Samples were at pH 7.5 in a $25 \mathrm{mM}$ HEPES buffer containing $100 \mathrm{mM} \mathrm{NaCl}, 1 \mathrm{mM}$ dithiothreitol, and $1 \mathrm{mM}$ EDTA. The concentration of ${ }^{15} \mathrm{~N}$ labeled RSV N(31-252) was $0.15 \mathrm{mM}$. Two-dimensional $\left[{ }^{15} \mathrm{~N},{ }^{1} \mathrm{H}\right]$ transverse relaxation optimized spectroscopy (TROSY) experiments were recorded with increasing ligand concentration [37]. Evolution times were approximately $53 \mathrm{~ms}$ in the ${ }^{1} \mathrm{H}$ dimension and $29 \mathrm{~ms}$ in the ${ }^{15} \mathrm{~N}$ dimension. The total acquisition time was 28 min per experiment.

To estimate the dissociation constant $\left(K_{d}\right)$ from NMR experiments, ${ }^{15} \mathrm{~N}$-RSV N(31-252) was titrated with a range of ligand concentrations. The weighted average of chemical shift changes $\left(\Delta \delta(\mathrm{N}, \mathrm{H})_{\mathrm{obs}}\right)$ is calculated using the following equation:

$$
\Delta \delta(\mathrm{N}, \mathrm{H})_{\mathrm{obs}}=\sqrt{\left(\Delta \delta_{\mathrm{HN}}\right)^{2}+\left(\Delta \delta_{\mathrm{N}} / 5\right)^{2}}
$$


where $\Delta \delta_{H N}$ and $\Delta \delta_{N}$ are the chemical shift changes of amide protons and nitrogens, respectively. Then $\Delta \delta(\mathrm{N}$, $\mathrm{H})_{\text {obs }}$ data were fitted by non-linear regression globally against the total concentration of the subtrate $\left(\mathrm{L}_{\mathrm{T}}\right)$ with the equation:

$$
\begin{aligned}
& \Delta \delta(\mathrm{N}, \mathrm{H})_{\text {obs }} \\
& =\Delta \delta(\mathrm{N}, \mathrm{H})_{\max } \frac{\left(\mathrm{K}_{\mathrm{d}}+\mathrm{L}_{\mathrm{T}}+\mathrm{E}_{\mathrm{T}}\right)-\sqrt{\left(\mathrm{K}_{\mathrm{d}}+\mathrm{L}_{\mathrm{T}}+\mathrm{E}_{\mathrm{T}}\right)^{2}-4\left(\mathrm{~L}_{\mathrm{T}} \mathrm{E}_{\mathrm{T}}\right)}}{2 \mathrm{E}_{\mathrm{T}}}
\end{aligned}
$$

where $\Delta \delta(\mathrm{N}, \mathrm{H})_{\max }$ is the maximum chemical shift difference, $\mathrm{E}_{\mathrm{T}}$ is the total concentration of $\mathrm{N}(31-352)$ in the solution, and $\mathrm{L}_{\mathrm{T}}$ is the total concentration of ligand.

\section{DNA manipulations and plasmid construction}

Plasmid DNA purification, PCR product purification, and gel extraction were performed using the QIAprep Spin Mini Plasmid Purification (Qiagen Inc., Valencia, CA), QuickStep $^{\text {Tw }} 2$ PCR Purification Kit (EdgeBio, Gaithersburg, $\mathrm{MD}$ ), and Rapid Gel Extraction Kit (Marligen Biosciences, Ijamsville, MD), respectively. Restriction enzymes and rAPid Alkaline Phosphatase were from Roche Applied Science (Indianapolis, IN). Primers for PCR DNA were from Eurofins MWG Operon (Huntsville, AL). All PCRs were performed with High Fidelity PCR Master (Roche Applied Science) using reaction conditions specified by the manufacturer. All ligation reactions were performed using the Rapid DNA Ligation Kit (Roche Applied Science) according to the manufacturer's instructions.

A DNA sequence codon optimized for expression in E. coli, encoding N-terminal $\mathrm{His}_{6}$-tagged RSV N(13-391) [strain A2, UniProtKB/Swiss-Prot: NCAP_HRSVA, P03418] was synthesized and cloned into pET-28b (GenScript, Piscataway, NJ). The plasmid was named pJT1128.

An expression plasmid was constructed for a Nterminal $\mathrm{His}_{6}$-tagged RSV N(31-252) as follows. A tobacco etch virus (TEV) protease cleavage recognition site was placed before the $\mathrm{His}_{6}$ tag for optional removal. This was accomplished by amplifying the gene encoding residues (31-252) by PCR from the codon-optimized sequence (see above for N(13-391)) using primers 31252For (5'-GG ATTCATATGGATTCCCATCGACACCCCGAACTAC-3') and 31253Rev (5'-GATGATGTCGACTTAGCCATAC GCGTTCATGAACAGACCAGCAA-3'). The purified PCR product was digested with NdeI and Sall and ligated into a modified pET-28b plasmid to make plasmid pJT1324. The ligation mixture was transformed into $E$. coli DH5 $\alpha$ chemically competent cells (Life Technologies, Grand Island, NY) and transformants were selected on Luria-Bertani (LB) agar supplemented with $30 \mu \mathrm{g} / \mathrm{ml}$ kanamycin. Transformants were analyzed by PCR, and plasmid DNA was isolated and sequenced for verification.
The gene sequence encoding a GST-tagged RSV P(1-241) construct was synthesized with codon optimization for expression in E. coli and cloned into pET-30a (BlueSky Bioservices, Worcester, MA). The plasmid was designated pJT1200.

The full length coding sequence (residues 1-241) for the human respiratory syncytial virus phosphoprotein P [strain A2, UniProtKB/Swiss-Prot: PHOSP_HRSVA, P03421] was synthesized in vitro by GeneArt AG (Life Technologies). The sequence was codon-optimized for Spodoptera frugiperda expression. The synthesized DNA fragment was restriction-cloned into a modified version of the pFastBac1 baculovirus expression vector (Life Technologies), downstream of an $\mathrm{N}$-terminal $\mathrm{His}_{10}$ tag and a TEV protease cleavage recognition sequence.

\section{Co-expression of RSV N(13-391) and RSV P (1-241)}

For protein production, the plasmids pJT1128 and pJT1200 were transformed into E. coli BL21(DE3)pLysS (EMD Chemicals, Gibbstown, NJ) and plated on LB medium containing $25 \mu \mathrm{g} / \mathrm{ml}$ kanamycin and $100 \mu \mathrm{g} / \mathrm{ml}$ ampicillin at $37^{\circ} \mathrm{C}$ overnight. A single colony of BL21(DE3)pLysS/pJT1128/ pJT1200 was inoculated into a 100-ml culture of LB containing $25 \mu \mathrm{g} / \mathrm{ml}$ kanamycin and $100 \mu \mathrm{g} / \mathrm{ml}$ ampicillin and grown overnight at $37{ }^{\circ} \mathrm{C}$. The overnight culture was diluted to $\mathrm{OD}_{600}=0.1$ in $4 \times 1 \mathrm{~L}$ of LB containing $25 \mu \mathrm{g} / \mathrm{ml}$ kanamycin and $100 \mu \mathrm{g} / \mathrm{ml}$ ampicillin and grown at $30^{\circ} \mathrm{C}$ with aeration to mid-logarithmic phase $\left(\mathrm{OD}_{600}=0.6\right)$. The culture was incubated on ice for 30 minutes and transferred to $18^{\circ} \mathrm{C}$. IPTG was then added to a concentration of 0.5 $\mathrm{mM}$. After overnight induction at $18^{\circ} \mathrm{C}$, the cells were harvested by centrifugation at $5,000 \mathrm{~g}$ for $15 \mathrm{~min}$ at $25^{\circ} \mathrm{C}$. Cell pastes were stored at $-20^{\circ} \mathrm{C}$.

\section{Purification of RSV N(13-391)}

The frozen cell paste from $4 \mathrm{~L}$ of cell culture was suspended in $50 \mathrm{ml}$ of Lysis Buffer consisting of $50 \mathrm{mM}$ Tris- $\mathrm{HCl}(\mathrm{pH} 8.0), 0.5 \mathrm{M} \mathrm{NaCl}, 5 \%(\mathrm{v} / \mathrm{v})$ glycerol, and 1 EDTA-free protease inhibitor cocktail tablet (Roche Molecular Biochemical, Indianapolis IN). Cells were disrupted by French Press at 18,000 psi twice at $4^{\circ} \mathrm{C}$. The crude extract was centrifuged at $150,000 \mathrm{~g}$ for $30 \mathrm{~min}$ at $4^{\circ} \mathrm{C}$. The supernatant was applied at a flow rate of $2.0 \mathrm{ml} / \mathrm{min}$ onto a 5-ml HiTrap $\mathrm{Ni}^{2+}$ chelating column (GE Healthcare Life Sciences, Piscataway NJ) pre-equilibrated with Buffer A consisting of $50 \mathrm{mM}$ Tris- $\mathrm{HCl}(\mathrm{pH} 8.0), 0.5 \mathrm{M} \mathrm{NaCl}$, and $5 \%$ glycerol. The column was then washed with Buffer $\mathrm{A}$, and eluted with a linear gradient from 0 to $0.5 \mathrm{M}$ imidazole in Buffer A. Fractions containing RSV N(13-391) were pooled and dialyzed against $1 \mathrm{~L}$ of Buffer $\mathrm{B}$ consisting of $50 \mathrm{mM}$ Tris- $\mathrm{HCl}$ (pH 8.0), $1 \mathrm{mM}$ EDTA, $1 \mathrm{mM}$ dithiothreitol, and $5 \%$ glycerol. The dialyzed sample was loaded at a flow rate of $2.0 \mathrm{ml} / \mathrm{min}$ onto a $20-\mathrm{ml} \mathrm{Q}$-Sepharose HP (HR16/10) column (GE Healthcare Life Sciences) 
pre-equilibrated with Buffer B. The column was washed with Buffer B and eluted with a linear gradient from 0 to $1 \mathrm{M} \mathrm{NaCl}$ in Buffer B. Fractions containing RSV N (13-391) were pooled and concentrated to $5 \mathrm{ml}$ by Amicon ${ }^{\circ}$ Ultracel-10K (Millipore, Billerica, MA). The $5 \mathrm{ml}$ sample was applied at a flow rate of $1.5 \mathrm{ml} / \mathrm{min}$ to a 120 -ml Superdex 200 (HR 16/60) column (GE Healthcare Life Sciences) pre-equilibrated and eluted with buffer consisting of 50 $\mathrm{mM}$ Tris- $\mathrm{HCl}$ (pH 8.0), $0.5 \mathrm{M} \mathrm{NaCl}, 1 \mathrm{mM}$ EDTA, $1 \mathrm{mM}$ dithiothreitol, and $5 \%$ glycerol. The fractions containing RSV N(13-391) were pooled and concentrated. The protein was characterized by SDS-PAGE and LC-MS, and the concentration was determined by the Bradford method [38]. The final yield of purified N(13-391) was $30 \mathrm{mg}$ from $4 \mathrm{~L}$ of cell paste. The protein was stored at $-80^{\circ} \mathrm{C}$. GST-RSV P (1-241) was not detectably expressed in the cells and none copurified with RSV-N(13-391). The ratio of UV absorbance at $280 \mathrm{~nm}$ to absorbance at $260 \mathrm{~nm}$ (A280/A260) was 2.2. No RNA was detected in the $\mathrm{N}(13-391)$ protein when $2 \mu \mathrm{g}$ of protein was run on an agarose gel and stained with ethidium bromide.

\section{Expression and purification of RSV N (31-252)}

The method for overexpression of $\mathrm{N}$ (31-252) was the same as for coexpression of $\mathrm{N}(13-391)$ and $\mathrm{P}$ (1-241) (see above), except using only plasmid pJT1324 and omitting ampicillin. The frozen cell paste from $4 \mathrm{~L}$ of cell culture was suspended in $50 \mathrm{ml}$ of Lysis Buffer consisting of 25 mM HEPES (pH 7.3), $0.5 \mathrm{M} \mathrm{NaCl}, 5 \%$ (v/v) glycerol, and 1 EDTA-free Protease inhibitor cocktail tablet. Cells were disrupted by French Press at 18,000 psi twice at $4^{\circ} \mathrm{C}$. The crude extract was centrifuged at $150,000 \mathrm{~g}$ for $30 \mathrm{~min}$ at $4^{\circ} \mathrm{C}$. The supernatant was applied at a flow rate of $2.0 \mathrm{ml} / \mathrm{min}$ onto a 5 -ml HiTrap $\mathrm{Ni}^{2+}$ chelating column (GE Healthcare Life Sciences) pre-equilibrated with Buffer C consisting of $25 \mathrm{mM}$ HEPES (pH 7.3), $0.5 \mathrm{M} \mathrm{NaCl}$, and $5 \%$ glycerol. The column was washed with Buffer $\mathrm{C}$, and eluted with a linear gradient from $0 \mathrm{M}$ to $0.5 \mathrm{M}$ imidazole in Buffer C. Fractions containing N (31-252) were pooled and concentrated to $5 \mathrm{ml}$. The $5-\mathrm{ml}$ sample was applied at a flow rate of $1.5 \mathrm{ml} / \mathrm{min}$ to a $120-\mathrm{ml}$ Superdex 200 (HR 16/60) column pre-equilibrated and eluted with buffer consisting of $25 \mathrm{mM}$ HEPES (pH 7.3), $0.5 \mathrm{M} \mathrm{NaCl}, 1 \mathrm{mM}$ EDTA, $1 \mathrm{mM}$ dithiothreitol, and 5\% glycerol. The fractions containing $\mathrm{N}$ (31-252) were pooled and concentrated. The protein was characterized by SDS-PAGE and LC-MS, and the concentration was determined by the Bradford method [38]. The final yield of purified $\mathrm{N}$ (31-252) was $135 \mathrm{mg}$ from $4 \mathrm{~L}$ of cell paste. The protein was stored at $-80^{\circ} \mathrm{C}$. A280/A260 was 2.6. No RNA was detected in the $\mathrm{N}(31-252)$ protein when $2 \mu \mathrm{g}$ of protein was run on an agarose gel and stained with ethidium bromide.

Uniformly ${ }^{15} \mathrm{~N}$-labeled N (31-252) was prepared by growing cells in M9 minimal medium supplemented with
$1 \mathrm{~g} / \mathrm{L}$ of $\left[{ }^{15} \mathrm{~N}\right] \mathrm{NH}_{4} \mathrm{Cl}$ and $10 \mathrm{~g} / \mathrm{L}$ glucose as the sole nitrogen and carbon sources. N (31-252) was purified as described above and stored in buffer consisting of $25 \mathrm{mM}$ HEPES (pH 7.3), $0.1 \mathrm{M} \mathrm{NaCl}, 1 \mathrm{mM}$ EDTA, and $1 \mathrm{mM}$ dithiothreitol. The extent of isotope labeling was $>93 \%$ ${ }^{15} \mathrm{~N}$ based on comparison of the observed mass with that expected from the sequence.

\section{Expression and purification of RSV P(1-241)}

Routine S. frugiperda (Sf21) cell maintenance, generation of bacmid DNA, generation of recombinant baculoviruses, expression studies in 24-deep-well blocks and roller bottles were carried out essentially as described in [39], except that no gentamicin antibiotic was added to insect cell cultures. SF900II medium for Sf21 cells was from Invitrogen. Fetal bovine serum (FBS) was from PAA Laboratories.

Insect cell pellets from $2 \mathrm{~L}$ of culture were thawed from $-80^{\circ} \mathrm{C}$ and resuspended by homogenization in $150 \mathrm{ml}$ of Lysis Buffer consisting of $50 \mathrm{mM}$ Tris- $\mathrm{HCl}$ ( $\mathrm{pH} \mathrm{8.0),} 300$ $\mathrm{mM} \mathrm{NaCl}, 10 \mathrm{mM}$ imidazole, $2 \mathrm{mM}$ tris(2-carboxyethyl) phosphine (TCEP), $1 \mathrm{mM}$ phenylmethylsulfonyl fluoride (PMSF), and 3 EDTA-free protease inhibitor tablets (Roche). Cells were lysed by sonication on ice $(5 \times 30$-s bursts) and clarified by centrifugation at $50,000 \mathrm{~g}$ for $1 \mathrm{~h}$ at $4^{\circ} \mathrm{C}$. The supernatant was loaded at $0.2 \mathrm{ml} / \mathrm{min}$ onto a 2-ml column of Ni-NTA Superflow resin (Roche). The column was washed with lysis buffer followed by buffer D, consisting of $50 \mathrm{mM}$ Tris- $\mathrm{HCl}$ (pH 8.0), $300 \mathrm{mM} \mathrm{NaCl}, 10$ $\mathrm{mM}$ imidazole, and $2 \mathrm{mM}$ TCEP, followed by additional washes at $20 \mathrm{mM}$ and $40 \mathrm{mM}$ imidazole in buffer D. Bound protein was eluted with $100 \%$ buffer E (buffer D with $300 \mathrm{mM}$ imidazole). Fractions containing RSV P protein based on SDS-PAGE were pooled and further purified by applying at a flow rate of $0.5 \mathrm{ml} / \mathrm{min}$ to a 120-ml Superdex 75 (XK26/60) gel filtration column (GE Healthcare Life Sciences) pre-equilibrated and eluted with buffer F consisting of $50 \mathrm{mM}$ Tris- $\mathrm{HCl}$ (pH 7.4), $200 \mathrm{mM}$ $\mathrm{NaCl}, 15 \%$ glycerol, and $1 \mathrm{mM}$ TCEP. The fractions with the highest purity as judged by SDS PAGE were pooled, snap-frozen in liquid nitrogen at $1.2 \mathrm{mg} / \mathrm{ml}$, and stored at $-80^{\circ} \mathrm{C}$. The final yield of purified RSV $\mathrm{P}(1-241)$ was $\sim 3$ $\mathrm{mg} / \mathrm{L}$ of cell paste. The His-tag was removed by TEV protease cleavage with a 1:200 ratio by weight of TurboTEV (Eton Bioscience, San Diego, CA) to RSV P(1-241) overnight at $4^{\circ} \mathrm{C}$. The protease was removed by adsorption to immobilized $\mathrm{Ni}^{2+}$ resin.

For the BP5 competition assay, the P protein storage buffer was replaced by repeated concentration using centrifugal ultrafiltration with a Millipore Ultrafree 0.5 unit with Biomax-10 membrane (EMD Millipore, Billerica, MA) and dilution with $10 \mathrm{mM}$ Tris- $\mathrm{HCl}(\mathrm{pH}$ 7.5). The protein concentration was determined by the method of Bradford [38] using bovine serum albumin as the standard. Serial 


\section{dilutions of $\mathrm{P}$ were prepared in $10 \mathrm{mM}$ Tris- $\mathrm{HCl}$ (pH 7.5) +0.01\% Brij-35.}

\section{Abbreviations}

P: Phosphoprotein; N: Nucleocapsid; N(13-391): Nucleocapsid with N-terminal truncation of 12 residues; N(31-252): Nucleocapsid construct consisting of residues 31-252: hRSV: Human respiratory syncytial virus:

RNP: Ribonucleoprotein; BP1: BODIPY-FL labeled peptide 1 (DSDNDLSLEDF); BP5: BODIPY-FL labeled peptide 5 (D(pS)DNDL(pS)LEDF); SPR: Surface plasmon resonance; HPLC: High-performance liquid chromatography; TOF: Time-of-flight; 2-D NMR: Two-dimensional nuclear magnetic resonance spectroscopy; LC-MS: Liquid chromatography-mass spectrometry; TCEP: Tris (2-carboxyethyl)phosphine hydrochloride; NHS: N-hydroxysuccinimide; RU: Resonance units; DMSO: Dimethyl sulfoxide; TROSY: Transverse relaxation optimized spectroscopy; TEV: Tobacco etch virus; LB: Luria-Bertani; GST: Glutathione-S-transferase; SDS-PAGE: Sodium dodecyl sulfate polyacrylamide gel electrophoresis; FBS: Fetal bovine serum; PMSF: Phenylmethylsulfonyl fluoride.

\section{Competing interests}

The authors declare that they have no competing interests.

\section{Authors' contributions}

ABS conceived of the study, carried out the fluorescence anisotropy measurements, and drafted the manuscript. NG expressed and purified RSV-N proteins and contributed to drafting the manuscript. NO'C performed SPR measurements and contributed to drafting the manuscript. JH performed NMR measurements and contributed to drafting the manuscript. JT prepared expression constructs and contributed to drafting the manuscript. RFG performed LC-MS measurements and contributed to drafting the manuscript. $\mathrm{RO}, \mathrm{IMH}$, and GGS prepared RSV-P expression constructs, purified the protein, and contributed to drafting the manuscript. All authors read and approved the final manuscript.

\section{Acknowledgments}

We thank Phil Ross for mass spectrometry of $\mathrm{P}$ protein and Stephania Livchak for removal of the His tag from P protein. This work was funded internally by AstraZeneca.

\section{Author details}

'Biology Department, Infection Innovative Medicines Unit, AstraZeneca R\&D Boston, Waltham, MA, USA. ${ }^{2}$ Reagents \& Assay Development, Discovery Sciences, AstraZeneca R\&D Boston, Waltham, MA, USA. ${ }^{3}$ Structure \& Biophysics, Discovery Sciences, AstraZeneca R\&D Boston, Waltham, MA, USA. ${ }^{4}$ Reagents \& Assay Development, Discovery Sciences, AstraZeneca Pharmaceuticals, Macclesfield, Cheshire, UK.

\section{Received: 18 September 2014 Accepted: 26 October 2014}

Published online: 19 November 2014

\section{References}

1. Walsh EE, Falsey AR: Respiratory syncytial virus infection in adult populations. Infect Disord - Drug Targets 2012, 12:98-102.

2. Collins PL, Melero JA: Progress in understanding and controlling respiratory syncytial virus: still crazy after all these years. Virus Res 2011, 162:80-99.

3. Najarro $P$, Angell $R$, Powell $K$ : The prophylaxis and treatment with antiviral agents of respiratory syncytial virus infections. Antivir Chem Chemother 2012, 22:139-150.

4. Meanwell NA, Langley DR: Inhibitors of protein-protein interactions in paramyxovirus fusion: a focus on respiratory syncytial virus. Top Med Chem 2012, 8:167-196.

5. Sudo K, Miyazaki Y, Kojima N, Kobayashi M, Suzuki H, Shintani M, Shimizu Y: YM-53403, a unique anti-respiratory syncytial virus agent with a novel mechanism of action. Antiviral Res 2005, 65:125-131.

6. Xiong $\mathrm{H}$, Foulk $\mathrm{M}$, Aschenbrenner $\mathrm{L}$, Fan J, Tiong-Yip $\mathrm{CL}$, Johnson $\mathrm{KD}$, Moustakas D, Fleming PR, Brown DG, Zhang M, Ferguson D, Wu D, Yu Q: Discovery of a potent respiratory syncytial virus RNA polymerase inhibitor. Bioorg Med Chem Lett 2013, 15:6789-6793.

7. Chapman J, Abbott E, Alber DG, Baxter RC, Bithell SK, Henderson EA, Carter MC, Chambers P, Chubb A, Cockerill GS, Collins PL, Dowdell VCL, Keegan SJ,
Kelsey RD, Lockyer MJ, Luongo C, Najarro P, Pickles RJ, Simmonds M, Taylor D, Tyms S, Wilson LJ, Powell KL: RSV604, a novel inhibitor of respiratory syncytial virus replication. Antimicrob Agents Chemother 2007, 51:3346-3353.

8. Liuzzi M, Mason SW, Cartier M, Lawetz C, McCollum RS, Dansereau N, Bolger G, Lapeyre N, Gaudette Y, Lagacé L, Massariol M-J, Dô F, Whitehead P, Lamarre L, Scouten E, Bordeleau J, Landry S, Rancourt J, Fazal G, Simoneau B: Inhibitors of respiratory syncytial virus replication target cotranscriptional mRNA guanylylation by viral RNA-dependent RNA polymerase. J Virol 2005, 79:13105-13115.

9. Tawar RG, Duquerroy S, Vonrhein C, Varela PF, Damier-Piolle L, Castagné N, MacLellan K, Beouelle H, Bricogne G, Bhella D, Eléouët J-F, Rey FA: Crystal structure of a nucleocapsid-like nucleoprotein-RNA complex of respiratory syncytial virus. Science 2009, 326:1279-1283.

10. El Omari K, Dhaliwal B, Ren J, Abrescia NGA, Lockyer M, Powell KL, Hawkins AR, Stammers DK: Structures of respiratory syncytial virus nucleocapsid protein from two crystal forms: details of potential packing interactions in the native helical form. Acta Cryst F Struct Biol Cryst Commun 2011, 67:1179-1183.

11. Llorente MT, Taylor IA, López-Viñas E, Gomez-Puertas P, Calder LJ, García-Barreno B, Melero JA: Structural properties of the human respiratory syncytial virus $P$ protein: evidence for an elongated homotetrameric molecule that is the smallest orthologue within the family of paramyxovirus polymerase cofactors. Proteins 2008, 72:946-958.

12. Castagné N, Barbier A, Bernard J, Rezaei H, Huet J-C, Henry C, Da Costa B, Eléouët J-F: Biochemical characterization of the respiratory syncytial virus $\mathrm{P}-\mathrm{P}$ and $\mathrm{P}-\mathrm{N}$ protein complexes and localization of the $\mathrm{P}$ protein oligomerization domain. J Gen Virol 2004, 85:1643-1653.

13. Galloux M, Tarus B, Blazevic I, Fix J, Duquerroy S, Eléouët J-F: Characterization of a viral phosphoprotein binding site on the surface of the respiratory syncytial virus. J Virol 2012, 86:8375-8387.

14. García-Barreno B, Delgado T, Melero JA: Identification of protein regions involved in the interaction of human respiratory syncytial virus phosphoprotein and nucleoprotein: significance for nucleocapsid assembly and formation of cytoplasmic inclusions. J Virol 1996, 70:801-808.

15. Tran T-L, Castagné N, Bhella D, Varela PF, Bernard J, Chilmoncyk S, Berkenkamp S, Benhamo V, Grznarova K, Grosclaude J, Nespoulos C, Rey FA, Eléouët J-F: The nine C-terminal amino acids of the respiratory syncytial virus protein $\mathrm{P}$ are necessary and sufficient for binding to ribonucleoprotein complexes in which six ribonucleotides are contacted per N protein protomer. J Gen Virol 2007, 88:196-206.

16. Mason SW, Aberg E, Lawetz C, DeLong R, Whitehead P, Liuzzi M: Interaction between human respiratory syncytial virus (RSV) M2-1 and P proteins is required for reconstitution of M2-1-dependent RSV minigenome activity. J Virol 2003, 77:10670-10676.

17. Esperante SE, Paris G, de Prat-Gay G: Modular unfolding and dissociation of the human respiratory syncytial virus phosphoprotein $\mathrm{P}$ and its interaction with the $\mathrm{M}_{2-1}$ antiterminator: a singular tetramer-tetramer interface arrangement. Biochemistry 2012, 51:8100-8110.

18. Blondot M-L, Dubosclard V, Fix J, Lassoued S, Aumont-Nicaise M, Bontems F, Eléouët J-F, Sizun C: Structure and functional analysis of the RNA- and viral phosphoprotein-binding domain of respiratory syncytial virus M2-1 protein. PLoS Pathog 2012, 8:e1002734.

19. Tran T-L, Castagné N, Dubosclard V, Noinville S, Koch E, Moudjou M, Henry C, Bernard J, Yeo RP, Eléouët J-F: The respiratory syncytial virus M2-1 protein forms tetramers and interacts with RNA and P in a competitive manner. J Virol 2009, 83:6363-6374.

20. Asenjo A, Calvo E, Villanueva N: Phosphorylation of human respiratory syncytial virus $\mathrm{P}$ protein at threonine 108 controls its interaction with the M2-1 protein in the viral RNA polymerase complex. J Gen Virol 2006, 87:3637-3642

21. Khattar SK, Yunus AS, Samal SK: Mapping the domains on the phosphoprotein of bovine respiratory syncytial virus required for N-P and P-L interactions using a minigenome system. J Gen Virol 2001, 82:775-779.

22. Noton SL, Deflubé LR, Tremaglio CZ, Fearns R: The respiratory syncytial virus polymerase has multiple RNA synthesis activities at the promoter. PLOS Pathog 2012, 8:e1002980.

23. Asenjo A, Mendieta J, Gómez-Puertas P, Villanueva N: Residues in human respiratory syncytial virus $P$ protein that are essential for its activity on RNA viral synthesis. Virus Res 2008, 132:160-173.

24. Tanner SJ, Ariza A, Richard C-A, Kyle HF, Dods RL, Blondot M-L, Wu W, Trincão J, Trinh $\mathrm{CH}$, Hiscox JA, Carroll MW, Silman NJ, Eléouët J-F, Edwards TA, Barr JN: 
Crystal structure of the essential antiterminator M2-1 protein of human respiratory syncytial virus and implications of its phosphorylation. Proc Natl Acad Sci U S A 2014, 111:1580-1585.

25. Cartee $T L$, Wertz GW: Respiratory syncytial virus M2-1 protein requires phosphorylation for efficient function and binds viral RNA during infection. J Virol 2001, 75:12188-12197.

26. Hardy RW, Wertz GW: The $\mathrm{Cys}_{3}$-His ${ }_{1}$ motif of the respiratory syncytial virus M2-1 protein is essential for protein function. J Virol 2000, 74:5880-5885.

27. García J, García-Barreno B, Vivo A, Melero JA: Cytoplasmic inclusions of respiratory syncytial virus-infected cells: formation of inclusion bodies in transfected cells that coexpress the nucleoprotein, the phosphoprotein, and the 22K protein. Virol 1993, 195:243-247.

28. Guo W, Wisniewski JA, Haitao J: Hot spot-based design of small-molecule inhibitors for protein-protein interactions. Bioorg Med Chem Lett 2014, 24:2546-2554

29. Mazumder B, Adhikary G, Barik S: Bacterial expression of human respiratory syncytial viral phosphoprotein $\mathrm{P}$ and identification of $\mathrm{Ser}^{237}$ as the site of phosphorylation by cellular casein kinase II. Virol 1994, 205:93-103.

30. Mazumder B, Barik S: Requirement of casein kinase II-mediated phosphorylation for the transcriptional activity of human respiratory syncytial viral phosphoprotein P: transdominant negative phenotype of phosphorylation-defective P mutants. Virol 1994, 205:104-111.

31. Barik S, McLean T, Dupuy LC: Phosphorylation of $\mathrm{Ser}^{232}$ directly regulates the transcriptional activity of the $\mathrm{P}$ protein of human respiratory syncytial virus: phosphorylation of $\mathrm{Ser}^{237}$ may play an accessory role. Virol 1995, 213:405-412.

32. Sánchez-Seco MP, Navarro J, Martinez R, Villanueva N: C-terminal phosphorylation of human respiratory syncytial virus $\mathrm{P}$ protein occurs mainly at serine residue 232 . J Gen Virol 1995, 76:425-430

33. Villanueva N, Hardy R, Asenjo A, Yu Q, Wertz G: The bulk of the phosphorylation of human respiratory syncytial virus phosphoprotein is not essential but modulates viral RNA transcription and replication. J Gen Virol 2000, 81:129-133.

34. Lu B, Ma C-H, Brazas $\mathrm{R}$, Jin H: The major phosphorylation sites of respiratory syncytial virus phosphoprotein are dispensable for virus replication in vitro. J Virol 2002, 76:10776-10784.

35. El Omari K, Scott K, Dhaliwal B, Ren J, Abrescia NGA, Budworth J, Lockyer M, Powell KL, Hawkins AR, Stammers DK: Crystallization and preliminary X-ray analysis of the human respiratory syncytial virus nucleocapsid protein. Acta Cryst F Struct Biol Cryst Commun 2008, 64:1019-1023.

36. Kleckner IR, Foster MP: An introduction to NMR-based approaches for measuring protein dynamics. Biochim Biophys Acta 1814, 2011:942-968.

37. Pervushin K, Riek R, Wider G, Wüttrich K: Attenuated T2 relaxation by mutual cancellation of dipole-dipole coupling and chemical shift anisotropy indicates an avenue to NMR structures of very large biological macromolecules in solution. Proc Natl Acad Sci U S A 1997, 94:12366-12371

38. Bradford MM: Rapid and sensitive method for the quantitation of microgram quantities of protein utilizing the principle of protein-dye binding. Anal Biochem 1976, 72:248-254.

39. McCall EJ, Danielsson A, Hardern IM, Dartsch C, Hicks R, Wahlberg JM, Abbott WM: Improvements to the throughput of recombinant protein expression in the baculovirus/insect cell system. Protein Express Purif 2005, 42:29-36.

doi:10.1186/s12985-014-0191-2

Cite this article as: Shapiro et al:: Quantitative investigation of the affinity of human respiratory syncytial virus phosphoprotein C-terminus binding to nucleocapsid protein. Virology Journal $2014: 191$. 